until the very end, the educational authorities succeeded in maintaining practically all the important research institutions and cultural associations remaining within the country. Scientific publications also continued to appear, and there was every reason to believe that the nation would, by hard labour, maintain its vigour and prosperity, and its men of science would be able to continue to achieve distinction and add to the sum of human knowledge by meritorious work in their respective fields. It is, perhaps, too early to foresee the consequences of the latest events in Central Europe. The new Protectorate is avowedly to have a measure of autonomy, though this is scarcely likely to go so far as to permit the free and open interchange of thought which has been banned in Germany for the past few years.

\section{Tuberculosis in Wales}

THE report is published of a Committee, consisting of Mr. Clement Davies and Dr. F. J. H. Coutts, appointed by Sir Kingsley Wood, when Minister of Health, in response to a request of the King Edward. VII Welsh National Memorial Association for an inquiry into the anti-tuberculosis service in Wales and Monmouthshire (London: H.M. Stationery Office. $4 s .6 d$. net). The problem of tuberculosis is relatively more serious in Wales than in England, for the mortality rate has not declined so rapidly as, and exceeds, that of England. Excessive mortality in Wales occurs among young adults aged fifteen to twenty-five years and in the age group twenty-five to forty-five. In contrast with England, the rates at fifteen to twenty-five show little change since 1921 and the rate for females is distressingly high. Certain areas, notably Anglesey, Caernarvon and Merioneth, are especially afflicted with the disease. The report states, that for practical purposes, racial susceptibility as a factor in causing the high mortality may be ignored. Segregation in tuberculosis is one of the most effectual preventive measures against the spread of the disease, the need for additional bed accommodation if tuberculosis is to be adequately dealt with is stressed, and it is suggested that, with a widely scattered population in some Welsh areas, small local institutions of a simpler type might be a valuable adjunct to the more fully equipped hospitals. The Committee recommends the provision of additional laboratory accommodation, and suggest that the proposal to establish a village settlement in Wales should be explored.

IT is pointed out that after-care work has made little headway in Wales, and although the Committee does not recommend that the Association should undertake this work, the hope is expressed that local authorities will realize the importance of setting up effective care organizations. Treatment is only one aspect of tuberculosis work, and the importance of preventive work should be realized. Unfortunately, over large areas in Wales, preventive duties are neglected or are carried out imperfectly by local authorities, who do not appear fully to realize their responsibilities. In regard to housing, the report states that in rural areas, villages and small towns there are hundreds of houses that are unfit for habitation. The Committee also points out that there is scope for much improvement in the pro. vision of milk and meals in schools, and authorities in Wales as a whole, with few exceptions, make little or no provision for midday meals. The Committee concludes by directing attention to the great disparity among local authorities in the standard of performance of public health services, and remarks that many of the authorities, owing to small population and inadequate resources of their area, are incapable of carrying out their public health duties properly. The Committee was impressed with the general efficiency of the Welsh National Memorial Association's work for the treatment of tuberculosis.

\section{Launch of the R.R.S. Research}

THE launching of the Admiralty non-magnetic ship, the R.R.S. Research, will take place at 6 p.m. on April 4 at the Noss Works, Dartmouth, of the builders Messrs. Philip and Son, Limited. The launching ceremony will be performed by Mrs. Spencer Jones, wife of the Astronomer Royal. The day and time of the launching have been chosen to coincide with the highest spring tides, as investigations proved that the Research, which is a 770-ton ship, would need all the water possible. The construction of a special vessel such as this, which is to be so far as possible non-magnetic, raises many problems. The question of the best substitutes for iron or steel in various components and fittings has required a good deal of investigation and experiment. The builders have shown a great interest in the work and have co-operated with the Admiralty to obtain the most satisfactory results. Lieut.-Commander D. H. Fryer, who has been appointed captain of the Research, was given special leave by the Admiralty to make a voyage to Australia in one of the grain ships in order to gain experience of sailing ships. $\mathrm{He}$ has recently completed the rigging of a scale water-line model of the Research, which will be on view at the reception to be given by Messrs. Philip and Son after the launching.

\section{Recent Researches in Steel Metallurgy}

IN a Friday evening discourse at the Royal Institution on March 17, Dr. W. H. Hatfield discussed what he described as the three principal aspects of steel research : (a) elucidation and improvement of the process of steel manufacture and manipulation; (b) the investigation of the properties of steel under variable conditions approximating to those of service; and $(c)$ the exploration of the influence of added elements and of the effect of heat-treatment. Dr. Hatfield showed a colour film illustrating the electric and open-hearth steel processes, the casting of ingots and forging operations. Dr. Hatfield said that one of the most complex studies is that of the changing properties of steels with varying temperature, this 